\title{
Characterization of the mucin phenotype can predict gastric cancer recurrence after endoscopic mucosal resection
}

\author{
Fabio Yuji HONDO', Humberto KISHI², Adriana Vaz SAFATLE-RIBEIRO², \\ Fernanda Cristina Simões PESSORRUSS0 ${ }^{1,4}$, Ulysses RIBEIRO JR $^{3}$ and Fauze MALUF-FILHO ${ }^{3}$
}

\begin{abstract}
Background - Endoscopic mucosal resection is still considered an accepted treatment for early gastric cancer for selected cases. Histopathologic criteria for curative endoscopic resection are intramucosal well-differentiated adenocarcinoma, lateral and deep margins free of tumor, no histological ulceration, and no venous or lymphatic embolism. A 5\% local recurrence rate has been described even when all the above-mentioned criteria are met. On the other hand, antigen expression by tumoral cells has been related to the biological behavior of several tumors. Objective - To evaluate whether early gastric cancer mucin immunoexpression, p53 and Ki-67, can predict recurrence after endoscopic mucosal resection, even when standard histopathologic criteria for curative measures have been attempted. Methods - Twenty-two patients with early gastric cancer were considered to have been completely resected by endoscopic mucosal resection. Local recurrence occurred in 5/22 (22.7\%). Immunohistochemical study was possible in 18 $(81.8 \%)$ resected specimens. Patients were divided in two groups: those with and those without local recurrence. They were compared across demographic, endoscopic, histologic data, and immunohistochemical factors for MUC2, MUC5a, CD10, p53, and Ki-67. Results - Mucin immunoexpression allowed a reclassification of gastric adenocarcinoma in intestinal (10), gastric (2), mixed (4), and null phenotypes (2). Mixed phenotype (positive for both MUC2 and MUC5a) was found in $80 \%$ of cases in the local recurrence group, while the intestinal type (positive MUC2 and negative MUC5a) was found in $76.9 \%$ of cases without local recurrence $(P=0.004)$. Other observed features did not correlate with neoplastic recurrence. Conclusion The mixed phenotype of early gastric adenocarcinoma is associated with a higher probability of local recurrence after endoscopic mucosal resection. HEADINGS - Stomach neoplasms. Endoscopic mucosal resection. Gastric mucins.
\end{abstract}

\section{INTRODUCTION}

Gastric adenocarcinoma that is limited to the mucosal layer, with no ulcer or scar tissue, does not usually present lymph node involvement ${ }^{(47)}$. This is the rationale for local resection with endoscopic mucosal resection (EMR), or mucosectomy. The local recurrence rate after EMR for gastric adenocarcinoma ranges from $2 \%$ to $35 \%{ }^{(11,59)}$. This is usually minimal for well-differentiated adenocarcinoma: en bloc resected, measuring up to $20 \mathrm{~mm}$ in size, restricted to the mucosa, and presenting without ulceration.

However, neoplastic cells may express some antigens, which are markers of a tumor's biological behavior. Moreover, welldifferentiated gastric carcinoma (Lauren's intestinal carcinoma) may display different phenotypic properties at an early stage, as demonstrated by mucin expression ${ }^{(23)}$.

Mucins are glycoproteins, the main component of the protective mucous layer of the mucosa. Twelve types of mucins have already been identified: Muc1, 2, 3, 4, 5a, 5b, 6, 7, 8, 9, 11, and 12. Muc1, Muc5a, and Muc6 expressions are present in the normal gastric mucosa, whereas Muc2 expression is the typical mucin of intestinal epithelium with goblet cells. Depending on mucin expression, metaplasia is divided into two groups: gastric and intestinal metaplasia. Muc5a, Muc6, and galactose are markers of gastric phenotype, whereas Muc2 and CD-10 are the intestinal subtype ${ }^{(43,65)}$. Similar to metaplasia, a subclassification of well-differentiated (Lauren's intestinal) cancer in phenotypes was established to better understand the biological $\mathrm{x}$ of these

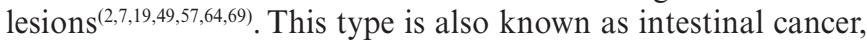
presenting with different phenotypes based on mucin expression: gastric, intestinal, mixed, or indeterminate types ${ }^{(10,50)}$. Gastric and mixed types tend to show greater agressive behavior, with increased potential for invasion and metastasis (even in early phases, similar to undifferentiated gastric carcinoma of the stomach) $)^{(5,29,46,50,53)}$.

The aim of this study was to evaluate whether expression of mucins, p53 and Ki-67, could predict risk of local recurrence of well-differentiated gastric adenocarcinoma (completely resected through EMR in patients followed for at least 1 year).

Declared conflict of interest of all authors: none

Disclosure of funding: no funding received

1 Gastrocirurgia, Faculdade de Medicina, Universidade de São Paulo, SP, Brasil; ${ }^{2}$ Patologia, Faculdade de Medicina, Universidade de São Paulo, SP, Brasil; ${ }^{3}$ Gastroenterologia, Universidade de São Paulo, SP, Brasil; ${ }^{4}$ Cirurgia Geral, Faculdade de Medicina de Jundiaí, SP, Brasil.

Correspondence: Fauze Maluf Filho. Departamento de Endoscopia, Instituto do Câncer de São Paulo. R. Dr. Arnaldo, 251, 2º andar - CEP 01246-000, São Paulo, SP, Brasil. E-mail: fauze. maluf@gmail.com 


\section{METHODS}

This was mostly a retrospective study in which patients with early gastric cancer who underwent EMR, by a single endoscopist, at Hospital das Clinicas of São Paulo University from June 1994 to December 2005 were included. The histologic evaluation of the specimens including immunohistochemistry studies were performed prospectively. Patients who had a complete resection were followed for one year. Those patients who were not submitted to surgical treatment after endoscopic resection were considered as cured.

Histopathologic complete resection was defined by the criteria below ${ }^{(18)}$ :

1. Intramucosal cancer;

2. Well-differentiated adenocarcinoma;

3. No histological ulcerations;

4. No lymphatic or venous invasion;

5. Lateral margins free of neoplasia.

The endoscopic follow-up consisted of quarterly scar biopsies in the first year, every 6 months in the second year, and annually thereafter. Patients were divided according to local recurrence during endoscopic follow-up. The two patient groups (with and without local recurrence of gastric adenocarcinoma) were compared for demographic, clinical, endoscopic, and histopathological aspects.

\section{Demographic data}

Gender (male or female), age (younger than 60 years old, or older than 60 years old), and race (white, black, or Asian origin).

\section{Endoscopic features}

Lesion size: lesions were classified according to size, and grouped as $2 \mathrm{~cm}$ or larger. To define lesion size, measurements by macroscopic examination of the resected specimen (and defined by the pathologist) were used for cases of en bloc resection. In piecemeal resection, measurements taken by the pathologist were also used; however, when lesion reconstruction was not possible, endoscopic measurement was considered.

Lesion location: according to the Japanese Gastric Cancer Association $^{(18)}$, this was classified in terms of upper, middle, and lower third of the stomach; in addition, it was classified by gastric circumference, either having a greater or lesser curvature as seen in the anterior and posterior wall.

Macroscopic type: this was used for Japanese classification, established by the Japanese Research Society for Gastric Cancer ${ }^{(38)}$. This classification includes lesions that present slight alterations on the mucosal surface, which may be assessed by endoscopic examination.

\section{Techniques applied to endoscopic resection}

a) Strip-biopsy or lift-and-cut technique (Figure 1 A-C) were first described by Tada et al. ${ }^{(54)}$.

b) Suck-and-cut or cap technique (Figure 1 D-E) were described by Inoue et al. ${ }^{(16)}$ and later modified by Torii et al. ${ }^{\left({ }^{(6)}\right)}$.

Number of resected fragments during mucosectomy: lesions were grouped into en bloc resection (single fragment) and piecemeal resection (two or more fragments).

Immunohistochemical profile of gastric adenocarcinoma: two pathologists prospectively reviewed all fragments of endoscopic or surgical resection. The resected specimens had a high likelihood of cure, and were submitted for another immunohistochemical profile prospectively. The immunohistochemical panel included the expression of Muc5A, Muc2, CD-10, p53, and Ki-67 markers.

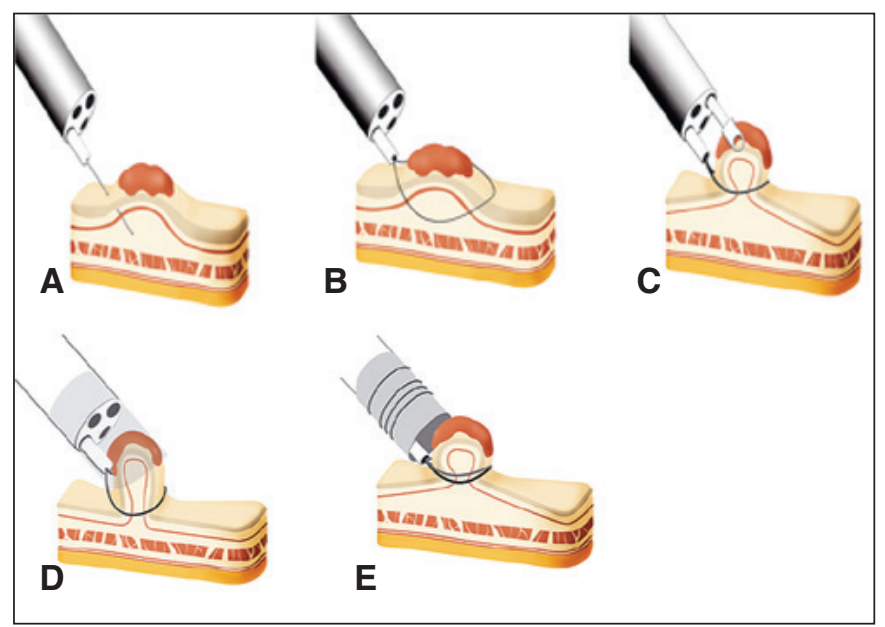

FIGURE 1. Endoscopic Mucosal Resection (EMR). A-C. Technique by strip-biopsy or lift and cut. A. Submucosal injection of saline solution. B. Polipectomy snare apreension. C. Alternative technique using doublechannel endoscope, a special forceps and a polipectomy snare. D-E. EMR by cap or suck and cut. D. Use of cap in association of polipectomy snare. E. Technical adaptation using rubber band ligation and polipectomy snare to resected.

\section{Mucins}

The streptavidin-biotin-peroxidase method (DAKO) was done in 4- $\mu \mathrm{m}$-sections of paraffin-embedded specimens for the immunohistochemical study of Muc-2 (Ccp58, Novocastra Laboratories, diluted 1:100, Newcastle, UK), Muc-5A (CLH2, Novocastra Laboratories, diluted 1:200), and CD-10 (56C6, Novocastra Laboratories, diluted 1:500). A search was performed for the staining of Muc-2 and Muc-5a in the cytoplasm of neoplastic cells. The CD-10 marker was considered positive when staining had a brush-border pattern on the luminal surface, which was then verified. Mucin cellular expression was considered positive when at least $5 \%$ of neoplastic cells expressed the marker per field of higher magnification (x40). Based on these markers, neoplasias were classified as gastric, intestinal, mixed, and indeterminate for mucins, shown in Table 1.

TABLE 1. Phenotypic Classifications of well differentiated adenocarcinoma

\begin{tabular}{lccc}
\hline Phenotype & Muc2 & Muc5A & CD-10 \\
\hline Gastric & - & + & - \\
Intestinal* & + & - & + \\
Mix** & + & + & + \\
Null & - & - & - \\
\hline
\end{tabular}

* Intestinal phenotype presents positive to marker Muc2 or CD-10. ** Mix phenotype presents positive to marker Muc2 and/or CD-10 associated to marker Muc5 A positive.

\section{Expression of p53 and Ki-67 monoclonal antibodies}

The streptavidin-biotin-peroxidase method for LSAB+ (DAKO) was used in 4- $\mu \mathrm{m}$-sections of paraffin-embedded specimens. Nuclear positivity of p53 markers was classified for intensity and distribution, whereas Ki-67 markers were classified for their distribution. The intensity of the p53 marker was stratified by: 0 - absence of staining; 1 - hardly visible staining; 2 - easily visible staining; 3 - intense staining in lesser degree than control; and 4 as intense as control group. 
The nuclear positivity of p53 and Ki-67 was evaluated for distribution pattern as: 0 - negative; 1 - rare cells (less than $2 \%$ ); 2 - small amount (2-20\%); 3 - moderate amount (20-75\%); and 4 - marked amount (more than $75 \%$ ).

Expression of $\mathrm{p} 53$ was considered positive when nuclear positivity was stratified in grade 3 or 4 , either for intensity or distribution. Ki-67 marker intensities for grade 3 or 4 were characterized as tumors with a high rate of proliferation.

\section{Statistical analysis}

Collected data were referred to as mean and standard deviation. Fisher's exact test was used to verify whether age, gender, lesion size, invasion level, macroscopic type, lesion location, endoscopic technique, number of fragments, and immunohistochemical markers (Muc5A, Muc2, CD-10, p53, and Ki-67) were also associated with a higher recurrence rate.

Statistical significance was used, and was established to be $P<0.05$.

\section{RESULTS}

Fifty-three patients underwent EMR for treatment of early gastric adenocarcinoma from June 1994 to December 2005. Recovered data existed from 46 of the total number of patients. Of 46 patients, 22 were identified to have a high likelihood of cure through EMR, as they presented differentiated histologic type, complete resection with free margins, no lymphatic or venous invasion, and tumoral invasion confined to the mucosal layer. Of the latter, $5(22.7 \%)$ presented local recurrence within a mean of $5.8 \pm 4.16$ months (range 1-18 months). All 5 patients with local recurrence were submitted to gastrectomy and have been cured, with no methastasis or recurrence.

Immunohistochemical studies were performed in $18(78.2 \%)$ resected specimens, since analysis of the remaining specimens was not possible due to the loss of resected material. Therefore, 18 patients were stratified according to recurrence, and paired for demographic data (age and gender) (Table 2), histopathologic data, and endoscopic features (endoscopic technique applied for resection, macroscopic type, number of resected fragments, and location) (Figure 2) (Table 3). There was no statistical difference in the studied clinicopathologic factors.

TABLE 2. Demographic parameters of recurrence and no recurrence subgroups in patients with high probability of cure

\begin{tabular}{lccc}
\hline $\begin{array}{l}\text { Demographic } \\
\text { parameters }\end{array}$ & No recurrence & Recurrence & $\boldsymbol{P}$ \\
\hline Gender & $02(15.4 \%)$ & $01(20 \%)$ & 0.308 \\
$\quad$ Female & $11(84.6 \%)$ & $04(80 \%)$ & \\
$\quad$ Male & & & \\
Age & $07(53.8 \%)$ & $04(80 \%)$ & 0.814 \\
$\quad<60$ years & $06(46.2 \%)$ & $02(20 \%)$ & \\
$\geq 60$ years & & & \\
Ethnicity & $09(69.2 \%)$ & $02(40 \%)$ & 0.145 \\
Caucasian & $02(15.4 \%)$ & 0 & \\
Afro-American & $02(15.4 \%)$ & $03(60 \%)$ & \\
Asian &
\end{tabular}

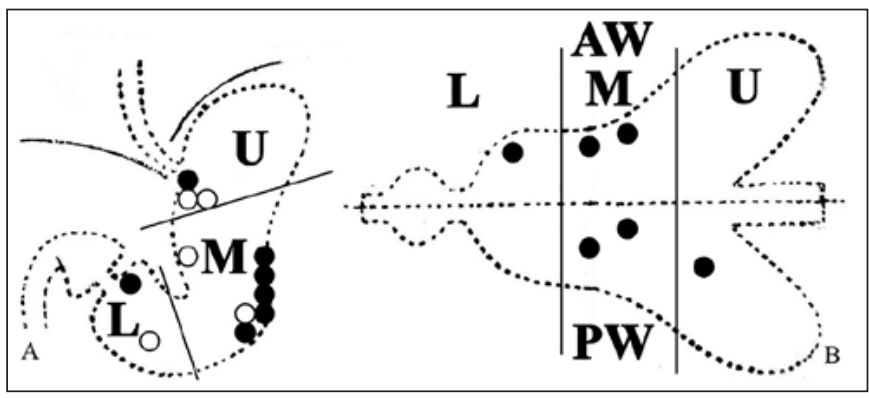

FIGURE 2. Localization of Early Gastric Cancer resected with high probability of cure with and without reccurrence. A. Localization of the cases at lesser or greater curvature in upper, middle and lower segments of stomach. B. Localization in upper, middle and lower segments at anterior or posterior stomach wall. No recurrence and $\bigcirc$ Recurrence. U: upper, M: middle, L: lower, LC: lesser curvature, GC: greater curvature, AW: anterior wall, PW: posterior wall.

TABLE 3. Parameters of recurrence and no recurrence subgroups in patients with high probability of cure after EMR of early gastric cancer

\begin{tabular}{lccc}
\hline Parameters & $\begin{array}{c}\text { No recurrence } \\
(\mathbf{n}=13)\end{array}$ & $\begin{array}{c}\text { Recurrence } \\
(\mathbf{n}=5)\end{array}$ & $\boldsymbol{P}$ \\
\hline $\begin{array}{l}\text { Technique } \\
\text { "CAP" }\end{array}$ & $01(7.7 \% \%)$ & $02(40 \%)$ & 0.099 \\
"Strip biospy" & $12(92.3 \%)$ & $03(60 \%)$ & \\
Macroscopic Type & & & \\
IIa & $09(69.2 \%)$ & $02(40 \%)$ & \\
IIc & $02(15.4 \%)$ & $03(60 \%)$ & 0.145 \\
IIa+IIc & $02(15.4 \%)$ & 0 & \\
\end{tabular}

Number of

fragment

$\begin{array}{lll}1 & 08(61.5 \%) & 03(60 \%) \\ \geq 2 & 05(38.5 \%) & 02(40 \%)\end{array}$

Invasion depht

\begin{tabular}{llll} 
m1 & $01(7.7 \%)$ & $01(20 \%)$ & \\
m2 & $06(46.2 \%)$ & $02(40 \%)$ & 0.758 \\
m3 & $06(46.2 \%)$ & $02(40 \%)$ & \\
\hline
\end{tabular}

Immunohistochemical study revealed that tumoral expression of Muc5A-type mucin was associated with a higher recurrence rate (Table 4) (Figure 3).

TABLE 4. Mucin marker expression, p53 and Ki-67 in intramucosal tumours in recurrence and no recurrence subgroups after EMR of early gastric cancer

\begin{tabular}{lccc}
\hline Markers & $\begin{array}{c}\text { No recurrence } \\
(\mathbf{n}=13)\end{array}$ & $\begin{array}{c}\text { Recurrence } \\
(\mathbf{n}=5)\end{array}$ & $\boldsymbol{P}^{*}$ \\
\hline Muc2 & $10(76.9 \%)$ & $5(100 \%)$ & 0.239 \\
Muc5A & $2(15.4 \%)$ & $4(80 \%)$ & 0.026 \\
CD10 & $3(23 \%)$ & 0 & 0.239 \\
p53 & $2(15.4 \%)$ & $2(40 \%)$ & 0.261 \\
Ki-67 & $5(38.4 \%)$ & $2(40 \%)$ & 0.952 \\
\hline
\end{tabular}

*Fischer's exact test 


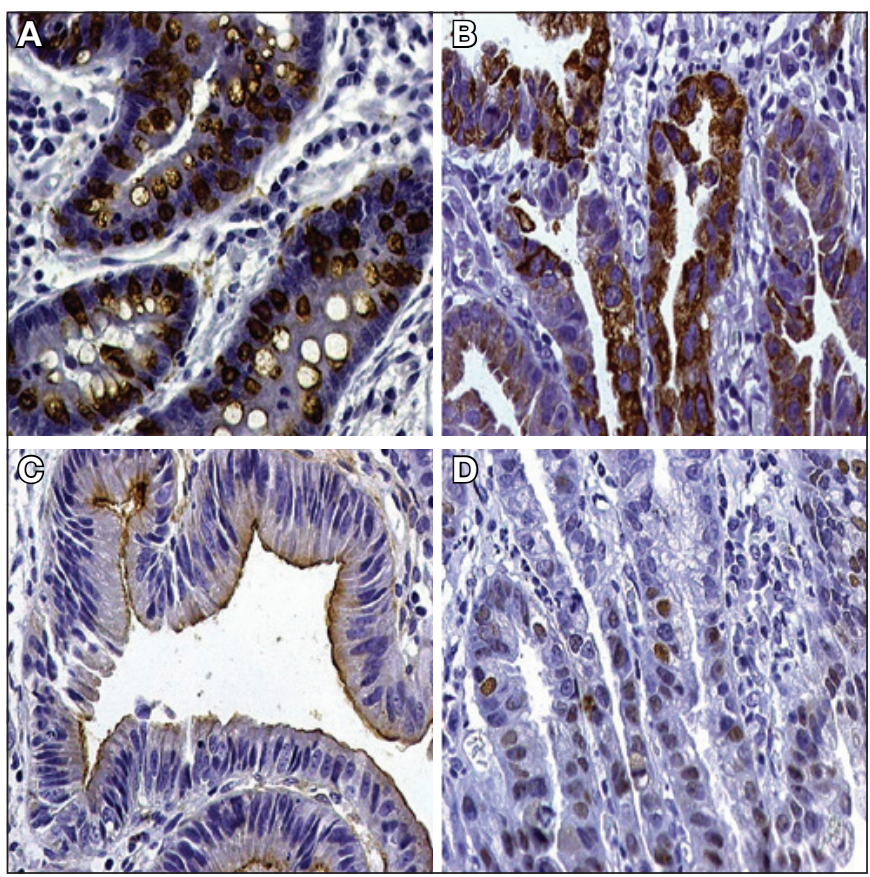

FIGURE 3. A. Cytoplasmic coloration of gastric cancer cells with expression of Muc2 marker in a case classified as mixed type (40X magnification). B. Cytoplasmic coloration of gastric cancer cells with expression of Muc5a marker in case classified as gastric type (40X magnification). C. Coloration of the brush border of the gastric cancer cells demonstrating the expression of the CD-10 mucinic marker in case classified as intestinal type (40X magnification). D. Positive staining of p53 marker (40X magnification).

In the recurrence group, four $(80 \%)$ patients had the mixed type, and one $(20 \%)$ had the intestinal type. In the group without recurrence, no patient had the mixed type, but $10(76.9 \%)$ had the intestinal type, $2(11.1 \%)$ had the gastric type, and $1(7.7 \%)$ had the indeterminate type (Table 5).

TABLE 5. Phenotypic type distribution of well differentiated adenocarcinoma in patients with high probability ou cure after EMR of EGC among the recurrence and no recurrence subgroups

\begin{tabular}{lccc}
\hline Phenotype & $\begin{array}{c}\text { No recurrence } \\
(\mathbf{n}=13)\end{array}$ & $\begin{array}{c}\text { Recurrence } \\
(\mathbf{n}=5)\end{array}$ & $\boldsymbol{P}^{*}$ \\
\hline Gastric & $02(15.4 \%)$ & 0 & \\
Intestinal & $10(76.9 \%)$ & $01(20 \%)$ & $0.004^{* *}$ \\
Mix & 0 & $04(80 \%)$ & \\
Null & $01(7.7 \%)$ & 0 & \\
\hline
\end{tabular}

*Fischer's exact test. ** Statistic difference between intestinal and mix types and groups with and without recurrence. There wasn't difference between the other phenotypes.

\section{DISCUSSION}

The classification of gastric cancer in two broad categories, along with different histogenesis and biological behavior, has been well established ${ }^{(27,31,36)}$. Gastric cancers are classified as intestinal, expanding, or differentiated, as well as diffuse, infiltrative, or undifferentiated. The first type is characterized by expanding growth and liver metastasis, occurring in elderly male patients. The second type presents infiltrative growth and peritoneal dissemination, with a higher incidence in young women ${ }^{(39)}$. Regarding carcinogenesis, the well-differentiated type originates in the atrophic gastric mucosa with intestinal metaplasia, while the undifferentiated type originates in the trophic gastric mucosa $\mathrm{a}^{(27,36,45,55)}$. Undifferentiated carcinoma can spread towards the submucosa with an increase in size, as well as presenting a higher risk of lymph node metastasis ${ }^{(62)}$. Patients with differentiated gastric carcinoma present a higher 5-year survival rate, compared to those with undifferentiated gastric carcinoma; the former may be an independent prognostic factor ${ }^{(17,34)}$. However, patients with differentiated tumors without serosa involvement, but with lymph node metastasis, are recognized to present a worse prognosis, compared to those with undifferentiated tumors ${ }^{(1)}$. Therefore, confounding situations of histogenesis and biological behavior, using this classification, can often be identified ${ }^{(34-36)}$.

Moreover, cases of differentiated type carcinoma with a pronounced trend toward invasion and metastasis, even in the early stage, have been observed ${ }^{(50)}$. In these cases, endoscopic resection is hindered by the likelihood of local recurrence or metastasis. In order to explain this unexpected biological behavior, immunohistochemical evaluations have acquired greater relevance.

Up to $50 \%$ of human cancers are estimated to present some mutation of the p53 gene $\mathrm{e}^{(4,25,26)}$. This alteration is involved in the carcinogenesis of gastric cancer, although this is not an independent factor $^{(44)}$. Some authors suggest its relation to late events of gastric cancer $^{(8,15)}$. Conversely, Ki-67 is a marker of cell proliferation and related to the prognosis of gastric cancer ${ }^{(70)}$. Higher rates of the Ki67 marker, associated with p53, are found to be useful markers for lymph node metastasis in patients with early gastric carcinoma ${ }^{(48)}$. In this study, p53 and Ki-67 markers were not found to be associated with tumor recurrence ${ }^{(15)}$.

Other markers are used to understand tumor biological behavior, e.g., mucin expression, through which subclassification of gastric cancer in phenotypes was established ${ }^{(2,7,14,19,49,64,66,69)}$. Thus, gastric tumors may express mucin phenotypes of gastric, intestinal, and mixed intestinal and gastric, or indeterminate types ${ }^{(10,50)}$.

The majority of differentiated adenocarcinomas are known to originate from intestinal metaplasia, presenting an intestinal phenotype $^{(7,27,36)}$. However, some originate from gastric mucosa without intestinal metaplasia, and were named as the gastric phenotype. Some studies demonstrated that this phenotype determines a higher potential of invasion and metastasis than the intestinal type, which resulted in a worse prognosis ${ }^{(23,37,50,56)}$. Early-stage cancer, with a gastric phenotype, demonstrated aggressive biological behavior, in comparison to the undifferentiated type ${ }^{(50)}$. The mixed phenotype presented intermediate aggressiveness ${ }^{(23,50,56)}$.

Encouraging results from immunohistochemical studies of gastric cancer show an increased understanding of gastric tumor carcinogenesis. Of note, differentiated adenocarcinoma with a gastric phenotype had results similar to those of undifferentiated adenocarcinoma, regarding prognosis and tumor biological behavior $^{(23,30,50,56)}$. Other authors consider the gastric phenotype of well-differentiated cancer an independent factor for lymph node metastasis, even at an early stage (19,23,50). $^{\text {. }}$

In this study, $22.7 \%$ of patients with differentiated intramucosal gastric cancer (totally resected with EMR) presented with local recurrence. In the literature, these rates usually range from $2.8 \%$ to $5.7 \%$, given this situation. The extremely high recurrence rate motivated the search for recurrence risk factors, including demographic, clinical, endoscopic, and immunohistochemical aspects. In the recurrence group, $2 / 5(40 \%)$ of patients were found to have piecemeal resection, while the remaining patients had en bloc resec- 
tion. Of these, the M3 layer was found to be involved in 3/5 (60\%) cases. However, neither the occurrence of piecemeal resection nor the depth of infiltration into the mucosa predicted local recurrence in our study. With known factors for local recurrence, piecemeal resection was brought to our attention. In the study conducted by Miyata et al. ${ }^{(32)}$, a larger lesion size was associated with a higher number of resected fragments, showing a significant difference but no relation to lesion location. Other studies demonstrated a larger lesion size, a lower rate of en bloc resection, even with different techniques and similar local recurrence rates of $1.7 \%$ and $2.3 \%$, respectively ${ }^{(11,58)}$. In this study, all 5 recurrences occurred with lesions smaller than $20 \mathrm{~mm}$, while 3 of them were resected en bloc, so that local recurrence could not be attributed to these risk factors. However, p53 and Ki-67 markers were not found to be related to local recurrence, likely confirming the fact that such markers are more strongly expressed in advanced gastric cancer, compared to early gastric cancer ${ }^{(15)}$.

The only predictive factor for local recurrence was a mixed phenotype, demonstrating the usefulness of immunohistochemical study for selection of patients for EMR. In the recurrence group, four $(80 \%)$ patients had mixed type and one $(20 \%)$ had intestinal type recurrence. Corroborating our data, Tajima et al. ${ }^{(49)}$ analyzed 63 gastric adenomas and 133 differentiated early gastric cancers, with 24 cases of gastric adenomas in a 2-year follow-up, presenting five cases of malignant transformation. The authors associated cases of malignant transformation to gastric and mixed phenotypes, characterized by HGM (human gastric mucin), MUC6, MUC2, and CD10 mucin markers. Kabashima et al. ${ }^{(20)}$ analyzed the expression of CD10, MUC2, HGM, and concanavalin, to be intramucosal differentiated tumors. By assessing these markers, they found the gastric phenotype in $36.8 \%(42 / 114)$. They demonstrated that the gastric phenotype group had more activity involving metalloproteinase ${ }^{(20)}$, which is associated with degradation of the extracellular matrix and facilitating tumor invasion and dissemination ${ }^{(6,31)}$. It is important to emphasize that some studies demonstrated how the biological behavior of a tumor with a gastric phenotype was comparable to an undifferentiated tumor ${ }^{(19,50,56)}$.

There is no consensus on the nature and number of antibodies that might be used to define a mucin phenotype of gastric carcinoma, or what percentage of positive tumor cells in each staining section must be used ${ }^{(3,19,21,22,23,24,28,42,51,56,63,67)}$. Shiroshita et al. ${ }^{(52)}$ suggested that to define a gastric phenotype, MUC5AC mucin or HGM must present in foveolar cells and MUC6 mucin, as well as in cells of the pyloric gland, which are part of the minimal panel to be investigated. For the intestinal phenotype, MUC2 mucins and CD10 must also be investigated. This research suggests that the immunohistochemical profile of mucin expression is a prognostic factor (after EMR of differentiated intramucosal early gastric cancer), as an integral part of the investigation for selected cases (before referral for minimally invasive therapy). In cases already submitted for treatment, in which the immunohistochemical profile of mucin expression was only possible after endoscopic treatment, the finding of mixed phenotype indicates a need for close followup or complementary therapy, plus a larger endoscopic or surgical resection, especially with a high risk of local recurrence.

With the development of a new mucosectomy technique, endoscopic submucosal dissection (ESD) ${ }^{(40)}$, en bloc resection rates were found to be $98 \%$ to $100 \%$ for lesions smaller than $2 \mathrm{~cm}^{(13,41,68)}$, and $79 \%$ to $97 \%$ for those larger than $2 \mathrm{~cm}^{(11,13,41)}$, along with local recurrence rates of 0 to $1 \%{ }^{(11,61,68)}$. In the present study, none of the 18 lesions was resected by ESD technique, since this technique had barely been introduced in Brazil at the time. Resections with larger safe margins and resection en bloc are believed to have curative capacity for lesions with more aggressive biological behavior. When compared to EMR, ESD is considered to be a more complex technique, with a longer learning curve. It is related to more complications, though, specifically perforation and bleeding ${ }^{(9)}$. It is possible that some centers will continue EMR for treatment of early gastric cancers, measuring up to $15 \mathrm{~mm}$. In this setting, we believe that mucin expression is useful to stratify risk for local cancer recurrence. We also believe that mucin expression should be studied to better stratify risk for local cancer recurrence, after expanded indication in ESD cases ${ }^{(12)}$.

In conclusion, our results suggest that mucin expression predicts local recurrence of early gastric cancers, after being treated with EMR. Moreover, gastric adenocarcinoma with mixed mucin phenotype expression was found to be a risk factor for local recurrence, in cases in which a high likelihood of cure was fulfilled.

\section{Authors' contributions}

Hondo FY performed the majority of experiments; Kishi $\mathrm{H}$, Safatle-Ribeiro AV and Ribeiro-Jr U provided analytical tools and were involved in manuscript editing; Pessorrusso FCS was in charge of data acquisition, and also involved in manuscript editing; Hondo FY performed the analysis and interpretation of data; Maluf-Filho $F$ revised the article and approved the final version for publication.

\section{Ethical standards}

All procedures were in accordance with the ethical standards of the Committee on Human Experimentation (institutional and national), as well as with the Helsinki Declaration of 1964 and its later versions.

\section{Disclosure}

This study is part of a master's degree thesis at University of São Paulo Medical School. The main text can be found at [http:// www.teses.usp.br/teses/disponiveis/5/5154/tde-20062007-161637/ pt-br.php]. Text in Portuguese (Br). 
Hondo FY, Kishi H, Safatle-Ribeiro AV, Pessorrusso FCS, Ribeiro Jr U, Maluf-Filho F. Caracterização dos fenótipos de mucina podem prever a recorrência do câncer gástrico precoce após a mucosectomia endoscópica. Arq Gastroenterol. 2017;54(4):308-14.

RESUMO - Contexto - A ressecção endoscópica da mucosa é tratamento aceito para o tratamento do câncer gástrico precoce em casos selecionados. Os critérios histopatológicos favoráveis à ressecção endoscópica curativa são adenocarcinomas intramucosos, bem diferenciados, com margens lateral e profunda livres, ausência de ulceração ou de embolização angiolinfática. Taxas de recorrência local próximas a 5\% têm sido descritas mesmo quando se cumprem tais critérios. Por outro lado, a expressão antigênica por células tumorais tem sido relacionada com o comportamento biológico de diversos tumores. Objetivo - Avaliar se a imunoexpressão de mucinas, p53 e Ki-67 podem predizer a recorrência tumoral após mucosectomia endoscópica no câncer gástrico precoce, mesmo se critérios de cura histopatológicos forem atingidos. Métodos - Vinte e dois pacientes com critérios de cura para ressecção endoscópica e sumetidos a mucosectomia foram selecionados. A recorrência local ocorreu em 5/22 (22,7\%). O estudo imunohistoquímico foi realizado em $18(81,8 \%)$ espécimens. Os pacientes foram divididos em grupos com e sem recorrência local. Foram comparados quanto a dados demográficos, endoscópicos, histológicos e fatores imunohistoquímicos para MUC2, MUC5A, CD10, p53, e Ki-67. Resultados - A imunoexpressão de mucinas permitiu a reclassificação dos adenocarcinomas gástricos em intestinal (10), gástrico (2), e de fenótipo misto (4) e nulo (2). Os fenótipos mistos (positivos tanto para MUC2 quanto para MUC5A) foram encontrados em 80\% dos casos no grupo de recorrência local, enquanto tipos intestinais (MUC2 positivo e MUC5A negativo) foram identificados em 76,9\% dos casos sem recorrência $(P=0,004)$. Os outros fatores observados não se relacionaram com a recorrência tumoral. Conclusão - O fenótipo misto do câncer gástrico precoce está associado a maior probabilidade de recorrência local após a mucosectomia.

DESCRITORES - Neoplasias gástricas. Ressecção endoscópica de mucosa. Mucinas gástricas.

\section{REFERENCES}

1. Adachi Y, Yasuda K, Inomata M, Sato K, Shiraishi N, Kitano S. Pathology and Prognosis of Gastric Carcinoma: well versus poorly differentiated type. Cancer. 2000;89:1418-24.

2. Ajioka Y, Watanabe H, Jass JR. MUC1 and MUC2 mucin in flat and polypoid colorectal adenomas. J Clin Pathol. 1997;50:417-21.

3. Amado M, Carneiro F, Seixas M, Clausen H, Sobrinho-Simoes M. Dimeric sialyl-Le(x) expression in gastric carcinoma correlates with venous invasion and poor outcome. Gastroenterology. 1998;114:462-70.

4. Brachmann RK. p53 mutants: the achilles' heel of human cancers? Cell Cycle. 2004;3:1030-4.

5. Chonan A, Mochizuki F, Ando M, Atsumi M, Mishima T, Fujita N, Yuki T, Ishida K. Endoscopic Mucosal Resection (EMR) of Early Gastric Cancer: Usefulness of Aspiration EMR Using a Cap-Fitted Scope. Dig Endosc. 1998;10:31-6.

6. David L, Nesland J, Holm R, Sobrinho-Simoes M. Expression of laminin, collagen IV, fibronectin and type IV collagenase in gastric carcinoma: an immunhistochemical study of 87 patients. Cancer. 1994;73:518-27.

7. Endoh Y, Tamura G, Motoyama T, Ajioka Y, Watanabe H. Well-differentiated adenocarcinoma mimicking complete-type intestinal metaplasia in the stomach. Hum Pathol. 1999;30:826-32.

8. Forones NM, Carvalho AP, Giannotti-Filho O, Lourenço LG, Oshima CT. Cell proliferation and apoptosis in gastric cancer and intestinal metaplasia. Arq Gastroenterol. 2005;42:30-4.

9. Goto O, Fujishiro M, Oda I, Kakushima N, Yamamoto Y, Tsuji Y, et al. A multicenter survey of the management after gastric endoscopic submucosal dissection related to postoperative bleeding. Dig Dis Sci. 2012;57:435-9.

10. Gotoda T, Yanagisawa A, Sasako M, Ono H, Nakanishi Y, Shimoda T, et al. Incidence of lymph node metastasis from early gastric cancer: estimation with a large number of cases at two large centers. Gastric Cancer. 2000;3:219-25.

11. Gotoda T, Yamamoto H, Soetikno RM. Endoscopic submucosal dissection of early gastric cancer. J Gastroenterol. 2006;41:929-42.

12. Gotoda T, Jung HY. Endoscopic resection (endoscopic mucosal resection/ endoscopic submucosal dissection) for early gastric cancer. Dig Endosc. 2013;25(Suppl 1):55-63.

13. Hamanaka H, Gotoda T. Endoscopic Resection for early gastric cancer and future expectations. Dig Endosc. 2005;17:275-85.

14. Han JP, Hong SJ, Kim HK, Kim HS, Lee YN, Lee TH, et al. Expression of immunohistochemical markers according to histological type in patients with early gastric cancer. Scand J Gastroenterol. 2016;51:60-6.

15. Igarashi N, Takahashi M, Ohkubo M, Omata K, Iida R, Fujimoto S. Predictive value of Ki-67, p53 protein, and DNA content in the diagnosis of gastric carcinoma. Cancer. 1999;86:1449-54

16. Inoue H, Takeshita K, Hori H, Muraoka Y, Yoneshima H, Endo M. Endoscopic mucosal resection with a cap-fitted panendoscope for esophagus, stomach, and colon mucosal lesions. Gastrointest Endosc. 1993;39:58-62.
17. Isozaki H, Tanaka N, Okajima K. General and specific prognostic factors of early gastric carcinoma treated with curative surgery. Hepatogastroenterology 1999;46:1800-8

18. Japanese Gastric Cancer Association. Japanese Classification of Gastric Cancer. Kanehara Publishers, Tokyo: 2nd English Edition. Gastric Cancer. 1998;1:10-24.

19. Kabashima A, Yao T, Shugimachi K, Tsuneyoshi M. Gastric and intestinal phenotypic expression in the carcinomas and background mucosa of multiple early gastric carcinomas. Histopathology. 2000;37:513-22.

20. Kabashima A, Yao T, Sugimachi K, Tsuneyoshi M. Relationship between biologic behavior and phenotypic expression in intramucosal gastric carcinomas. Hum Pathol. 2002;33:80-6.

21. Katsuyama T, Spicer SS. Histochemical differentiation of complex carbohydrates with variants of the concanavalin A-horseradish peroxidase method. J Histochem Cytochem. 1978;26:233-50.

22. Kawachi H, Takizawa T, Eishi Y, Shimizu S, Kumagai J, Funata N, et al. Absence of either gastric or intestinal phenotype in microscopic differentiated gastric carcinomas. J Pathol. 2003;199:436-46.

23. Koseki K, Takizawa T, Koike M, Ito M, Nihei Z, Sugihara K. Distinction of differentiated type early gastric carcinoma with gastric type mucin expression. Cancer. 2000;89:724-32.

24. Kurihara N, Kubota T, Otani Y, Ohgami M, Kumai K, Sugiura H, et al. Lymph node metastasis of early gastric cancer with submucosal invasion. Br J Surg. 1998; $85: 835-9$

25. Lane DP. Cancer. p53, guardian of the genome. Nature. 1992;358:15-6.

26. Lane DP, Crawford LV. T antigen is bound to a host protein in SV40-transformed cells. Nature. 1979;278:261-3.

27. Lauren P. The two histologic main types of gastric carcinoma: diffuse and socalled intestinal-type carcinoma: an attempt at a histo-clinical classification. Acta Pathol Microbiol Scand. 1965;64:31-49.

28. Lee HS, Lee HK, Kim HS, Yang HK, Kim YI, Kim WH. MUC1, MUC2, MUC5AC, and MUC6 expressions in gastric carcinomas. Cancer. 2001;92:1427-34.

29. Machado JC, Nogueira AM, Carneiro F, Reis CA, Sobrinho-Simoes M. Gastric carcinoma exhibits distinct types of cell differentiation: an immunohistochemical study of trefoil peptides (TFF1 and TFF2) and mucins (MUC1, MUC2, MUC5AC, and MUC6). J Pathol. 2000;190:437-43.

30. Min BH, Kim KM, Park CK, Lee JH, Rhee PL, Rhee JC, et al. Outcomes of endoscopic submucosal dissection for differentiated-type early gastric cancer with histological heterogeneity. Gastric Cancer. 2015;18:618-26.

31. Ming SC. Gastric carcinoma: a pathobiological classification. Cancer. 1977;39: 2475-85.

32. Miyata M, Yokoyama Y, Okoyama N, Joh T, Seno K, Sasaki M, et al. What are the appropriate indications for endoscopic mucosal resection for early gastric cancer? Analysis of 256 endoscopically resected lesions. Endoscopy. 2000; $32: 773-8$. 
33. Murray GI, Duncan ME, O’Neil P, Melvin WT, Fothergill JE. Matrix metalloproteinase- 1 is associated with poor prognosis in colorectal cancer. Nat Med. $1996 ; 2: 461-2$

34. Nagayo T. Microscopical cancer of the stomach: a study on histogenesis of gastric carcinoma. Int J Cancer. 1975;16:52-60.

35. Nakahara K. Special features of intestinal metaplasia and its relation to early gastric carcinoma in man: observation by a method in which leucine aminopeptidase activity is used. J Natl Cancer Inst. 1978;61:693-702.

36. Nakamura K, Sugano H, Takagi K. Carcinoma of the stomach in incipient phase: Its histogenesis and hitological appearances. Gan. 1968;59:251-8.

37. Nie L, Li M, He X, Feng A, Wu H, Fan X. Gastric mixed adenoneuroendocrine carcinoma: correlation of histologic charactistics with prognosis. Ann Diagn Pathol. 2016;25:48-53.

38. Nishi M, Ishihara S, Nakajima T, Ohta K, Ohyama S, Ohta H. Chronological changes of characteristics of early gastric cancer and therapy: experience in the Cancer Institute Hospital of Tokyo, 1950-1994. J Cancer Res Clin Oncol. 1995; $121: 535-41$.

39. Noda S, Soejima K, Inokuchi K. Clinicopathological analysis of the intestinal type and diffuse type of gastric carcinoma. Jpn J Surg. 1980;10:277-83.

40. Ono H, Kondo H, Gotoda T, Shirao K, Yamaguchi H, Saito D, et al. Endoscopic mucosal resection for treatment of early gastric cancer. Gut. 2001:48:225-9.

41. Oyama T, Kikuchi Y. Aggressive endoscopic mucosal resection in the upper GI tract - hook knife EMR method. Minim Invasive Ther Allied Technol. 2002;11:291-5.

42. Pinto-de-Souza J, David L, Reis CA, Gomes R, Silva L, Pimenta A. Mucins MUC1, MUC2, MUC5AC and MUC6 expression in the evaluation of differentiation and clinico-biological behaviour of gastric carcinoma. Virchows Arch. 2002;440:304-10.

43. Reis CA, David L, Correa P, Carneiro F, de Bolos C, Garcia E, et al. Intestinal metaplasia of human stomach displays distinct patterns of mucin (MUC1, MUC2, MUC5AC, and MUC6) expression. Cancer Res. 1999;59:1003-7.

44. Rhyu MG, Park WS, Jung YJ, Choi SW, Meltzer SJ. Allelic deletions of MCC APC and p53 are frequent late events in human gastric carcinogenesis. Gastroenterology. 1994;106:1584-8.

45. Saito K, Shimoda T. Histogenesis and early invasion of gastric cancer. Acta Pathol Jpn. 1986;36:1307-18

46. Saito A, Shimoda T, Nakanishi Y, Ochiai A, Toda G. Histologic heterogeneity and mucin phenotypic expression in early gastric cancer. Pathol Int. 2001;51 165-71.

47. Sano T, Kobori O, Muto T. Lymph nodes metastasis from early gastric cancer: endoscopic resection of tumour. Br J Surg. 1992;79:241-44

48. Sasaki O, Kido K, Nagahama S. DNA ploidy, Ki-67 and p53 as indicators of lymph node metastasis in early gastric carcinoma. Anal Quant Cytol Histol. 1999;21:85-8.

49. Sato Y, Itoh F, Hinoda Y, Ohe Y, Nakagawa N, Ueda R, et al. Expression of CD 10/neutral endopeptidase in normal and malignant tissue of human stomach and colon. J Gastroenterol. 1996;31:12-7.

50. Shibata N, Watari J, Fujiya M, Tanno S, Saitoh Y, Kohgo Y. Cell kinetics and genetic instabilities in differentiated type early gastric cancers with different mucin phenotype. Hum Pathol. 2003;34:32-40.

51. Shimada S, Matsuzaki H, Marutsuka T, Shiomori K, Ogawa M. Gastric and intestinal phenotypes of gastric carcinoma with referece to expression of brain (fetal)-type glycogen phosporylase. J Gastroenterol. 2001;36:457-64

52. Shiroshita H, Hidenobu W, Ajioka Y, Watanabe G, Nishikura K, Kitano S. Re-evaluation of mucin phenotypes of gastric minute well-differentiated-type adenocarcinomas using a series of HGM, MUC5AC, MUC6, M-GGMC, MUC2 and CD-10 stains. Pathol Int. 2004;54:311-21.
53. Sugai T, Inomata M, Uesugi N, Jiao YF, Endoh M, Orii S, et al. Analysis of mucin, p53 protein and $\mathrm{Ki}-67$ expressions in gastric differentiated-type intramucosal neoplastic lesions obtained from endoscopic mucosal resection samples: A proposal for a new classification of intramucosal neoplastic lesions based on nuclear atypia. Pathol Int. 2004:54:425-35.

54. Tada M, Yanai H, Takemoto T. New technique of gastric biopsy. Stomach Intestine. 1984:19:1107.

55. Tahara E. Genetic alterations in human gastrointestinal cancers: the application to molecular diagnosis. Cancer. 1995;75(6 Suppl):1410-7.

56. Tajima Y, Shimoda T, Nakanishi Y, Yokoyama N, Tanaka T, Shimizu K, et al. Gastric and intestinal phenotypic marker expression in gastric carcinomas and its prognostic significance: immunohistochemical analysis of 136 lesions Oncology. 2001;61:212-20

57. Tajima Y, Yamazaki K, Makino R, Nishino N, Aoki S, Kato M, et al. Gastric and intestinal phenotypic marker expression in early differentiated-type tumors of the stomach: clinicopathologic significance and genetic background. Clin Cancer Res. 2006;12:6469-79.

58. Takeshita K, Tani M, Inoue H, Saeki I, Honda T, Kando F, et al. A new method of endoscope mucosal resection of neoplastic lesions in the stomach: its technical features and results. Hepatogastroenterology. 1997;44:1602-11

59. Tanabe S, Koizumi W, Mitomi H, Nakai K, Murakami S, Nagaba S, et al Clinical outcome of endoscopic aspiration mucosectomy for early stage gastric cancer. Gastrointest Endosc. 2002;56:708-13.

60. Torii A, Sakai M, Kajiyama T, Kishimoto H, Kin G, Inoue K, et al. Endoscopic aspiration mucosectomy as curative endoscopic surgery: analysis of 24 cases of early gastric cancer. Gastrointest Endosc. 1995;42:475-9.

61. Toyonaga T, Man-i M, East JE, Nishino E, Ono W, Hirooka T, et al. 1,635 Endoscopic submucosal dissection cases in the esophagus, stomach, and colorectum complication rates and long-term outcomes. Surg Endosc. 2013;27:1000-8.

62. Tsujitani S, Oka S, Saito H, Kondo A, Ikeguchi M, Maeta M, et al. Less invasive surgery for early gastric cancer based on the low probability of lymph node metastasis. Surgery 1999;125:148-54.

63. Tsukashita S, Kushima R, Bamba M, Sugihara H, Hattori T. MUC gene expression and histogenesis of adenocarcinoma of the stomach. Int J Cancer. 2001;94:166-70.

64. Tytgat KM, Buller HA, Opdam FJ, Kim Ys, Einerhand AW, Dewwer J. Biosynthesis of human colon mucin: MUC2 is prominent secretory mucin. Gastroenterology. 1994;107:1352-63.

65. Wada R, Yamaguchi T, Tanizaki T. Mucin phenotypic expression and p53 gene abnormality of gastric super-minute well-differentiated adenocarcinoma: re-evaluation with relationship between histogenesis of well-differentiated adenocarcinoma and intestinal metaplasia in distal stomach. J Carcinog. 2005;4:1-7.

66. Wang XT, Kong FB, Mai W, Li L, Pang LM. Mucl immunohistochemical expression as a prognostic factor in gastric cancer: meta-analysis. Dis Markers. 2016;2016:9421571.

67. Watanabe G, Watanabe H, Ajioka Y, et al. Well-differentiated type adenocarcinoma of gastric mucin phenotype transform into intestinal type carcinomas. Stomach Intestine. 2003;38:693-700.

68. Yamamoto H, Kawata H, Sunada K, Sasaki A, Nakazawa K, Miyata T, et al. Successful en bloc resection of large superficial tumors in the stomach and colon using sodium hyaluronate and small-caliber-tip transparent hood. Endoscopy. 2003;35:690-4

69. Yao T, Kabashima A, Kouzuki T, et al. The phenotypes of the gastric carcinoma: evaluation by a new immunohistochemical method. Stomach Intestine 1999;34:477-86.

70. Young GA, Hedley DW, Rugg CA, Iland HJ. The prognostic significance of proliferative activity in poor histology non-Hodgkin's lymphoma: a flow cytometry study using archival material. Eur J Cancer Clin Oncol. 1987;23:1497-504. 